\title{
Computer Tomography in Comparison with Other Testing Methods Used for the Leakage Testing of HPDC Parts
}

Stunová Barbora, Novotný Filip

CTU in Prague, Faculty of Mechanical Engineering, Departement of Manufacturing technology CTU in Prague, Technická 4, 16607 Praha 6. E-mail: barbora.stunova@fs.cvut.cz

Prokop Josef, Faculty of Nuclear Sciences and Physical Engineering, Department of Physical Electronics, Břehová 7, 11519

Praha 1. E-mail: josef.prokop@fjfi.cvut.cz

Computer tomography could be used for non-destructive inspection of castings. This contribution deals with application of computer tomography for determination of inner quality of high-pressure die casting parts, especially in relation to leakage and compared with other testing methods. In praxis, the leakage location is identified by fracture test or by metallographic observation. Often the oxides and porosity are found. Porosity is also often found out after machining operations. This work proposes non-destructive methods of castings inspection, especially tomography, in comparison of other known and available methods, with the goal to find out the problem before machining with minimal losses.

Keywords: Pressure Tightness, Leakage, High Pressure Die Casting, Computer Tomography.

\section{References}

[1] CEJP, J. - PLEŠINGER, P.: Využití počítačové tomografie při stanovení porezity hliníkové slitiny. In: Konference Aluminium 2009. [Sborník.]. Košice : 2009. s. 120 - 125. ISSN 1335-2334.

[2] MICHNA, Š.: Encyklopedie hliníku. Prešov, Adin, 2005.

[3] WALKINSON, W. G. Die Casting Defects-Causes and Solutions. Rosemont: NADCA, 1997.

[4] BOLIBRUCHOVÁ, D. - KANTORÍK, R. - PASTIRČÁKOVÁ, M.: Chyby hliníkových odliatkov odlievaných metódou vysokotlakového odlievania. Slévárenství, č. $9-10 / 2008$, s. $422-426$.

[5] DUBENSKÝ, R. - MINAŘíK, V. - ČERMÁK, F.: Defektoskopie - nedestruktivní zkoušení. Praha, ČVUT, 1992. $206 \mathrm{~s}$.

[6] ELBEL, T.: Identifikace vad odlitků a príčin jejich zniku. Slévárenství - Vady odlitků. 9/2001, str. 499-503.

[7] LUKÁČ, I. - MICHNA, Š.: Strukturní vady u slitin na bázi Al-Si a jejich identifikace aplikací faktografické, EDX a metalografické analýzy. Slévárenství 11-12/2000, str. 571-576.

[8] MICHNA, Š. - KUŚMIERCZAK, S.: Vady na eloxovaném povrchu a eloxovatelnost hliníkových slitin. Strojírenská technologie, 2009, roč. XIV, č. 2, str. 21-27. ISSN 1211-4162.

[9] PTÁČEK, L.: Vady odlitků ze slitin hliníku. Slévárenství 9-10/1998, str. 371-376.

[10] MICHNA, Š. - VOJTĚCH, D. - MAJRICH, P.: Problematika kvality Al taveniny při lití automobilových disků. Strojirrenská technologie, 2008, roč. XIII, č. 3, str. 17-23. ISSN 1211-4162.

Reviews:

Prof. Přemysl Pokorný, MSc., Ph.D. Assoc. Prof. Stefan Michna, MSc., PhD. 